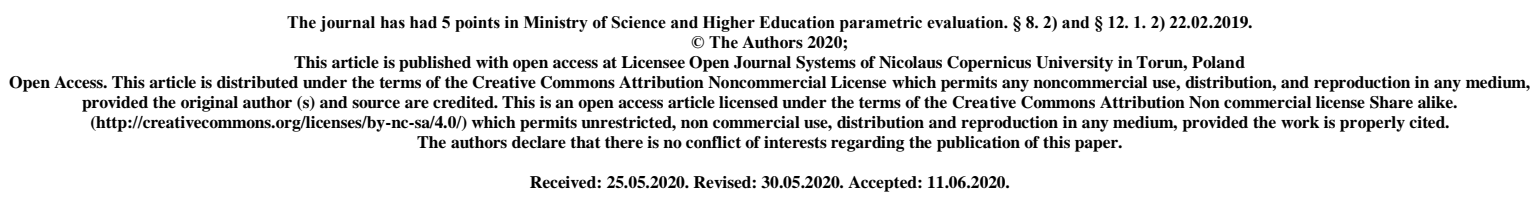

\title{
Detection of carbonates in water softeners
}

\section{Kinga Andrusiewicz, Mirella Czapska, Barbara Nieradko-Iwanicka}

Name

Affiliation

Country

Bio Statement

Name

Affiliation

Country

Bio Statement

Name

ORCID iD

Affiliation

Country

Bio Statement
Kinga Andrusiewicz

Students' Scientific Association at the Chair and Department of Hygiene, Medical University of Lublin

Poland

student

Mirella Czapska

Chair and Department of Epidemiology and Methodology of Clinical Trials, Medical University of Lublin

Poland

technitian

Barbara Nieradko-Iwanicka

http://orcid.org/0000-0002-4839-6003

Chair and Department of Hygiene, Medical University of Lublin

Poland

associate professor

Principal contact for editorial correspondence. 


\begin{abstract}
The skin is one of the most important and the largest organ of human body. Skin hygiene requires use of water. Water can be hard. Hard water effectively hinders the washing process. The purpose of the work is to detect carbonates in bath salts and water softeners.

Materials and methods

A total of 80 samples were collected: micellar fluids-5, tonics-6, shampoos-17, shower gels-6, bath salts-13, soaps-11, washing gels-6, softeners-3, washing capsules-3, washing powders-4, dishwasher tablets-5, bathwatercolour-1.

One gram of test substance was added to $10 \mathrm{~cm} 3$ of distilled water, heated until the precipitate dissolved and poured into a tube. A few drops of $3 \mathrm{~mol} / \mathrm{dm} 3 \mathrm{H} 2 \mathrm{SO} 4$ were added. The evolution of gas bubbles indicated the presence of carbonates.

In our experiment we have found the presence of bicarbonate only in effervescent tablets for baby baths, Salt Iwonicka and in bathing balls.

Conclusions: Not all products containing "bath salt" contain bicarbonate. Budget bath salts in the composition have sodium chloride or sodium lauryl sulphate, but they do not contain bicarbonate. Micellar liquids, shower gels, face wash gels, soaps, shampoos, powders and liquids for washing and rinsing fabrics, dishwasher products do not contain carbonates. The most bicarbonate salt contains Iwonicka Salt. Detergents such as washing powders, washing liquids and fabric rinses and dishwasher products contain phosphonates, which give off abundant foam.
\end{abstract}

Key words: carbonates; water softeners; hard water; skin

\title{
Introduction
}

The skin is one of the most important and also the largest organ of human body. It is a protective barrier, a place where sensors of temperature, pain and touch are located. It is also crucial for temperature regulation. It consists of subcutaneous tissue, dermis and epidermis. In order to prevent its damage, one must take care of it every day, by nutrition, thorough cleaning, washing or bathing. Unfortunately, processes that require the use of water can sometimes be difficult. This is because water can be hard. Hard water effectively hinders the washing process. The degree of water hardness depends on the presence of calcium and magnesium ions in it. Hard water needs more detergents and soaps. In order to soften the water, a suitable detergent is added to it, which reduces its surface tension. According to World Health Organization (WHO), medium hardness water is preferred for consumption and hygiene. Soft water, ideal for washing, may have an adverse effect on the mineral balance of the human body [1].

The degree of water hardness is greatly influenced by the presence of calcium and magnesium ions. The presence of these ions in drinking water results in the tea having an unappetizing appearance and bitter taste, and on its surface there are dark spots, settling on the dish from which we drink. Water hardness also determines the formation of scale at the bottom of the kettle, in which we boil water for this tea [2].

Water hardness means the content of salts dissolved in it, which mainly include calcium and magnesium salts. These salts give the water a characteristic feature called hardness [3]. Hardness strongly affects the surface tension of water. This means that the greater its surface tension, the more difficult it is to perform activities such as washing. You can reduce the water hardness by adding a suitable detergent. Softening salts are also used to reduce water hardness. 
There are several types of water hardness. The first is general hardness, sometimes called total hardness, for raw water. It is the sum of transient and constant hardness. The second type is permanent hardness, which applies to water boiled. This type of hardness is affected by salts that do not deposit on the walls of the kettle during cooking. These include a group of sulfates, chlorides, nitrates and neutral carbonates. The third type of hardness is transient hardness, called transient, caused by calcium and magnesium acid carbonates, precipitating as a result of boiling water [4]. This type is the difference between general and permanent hardness.

Parallel to the above classification of water hardness, a different division according to the chemical composition of calcium and magnesium salts present in water is often used [3].

I Carbonate hardness - caused by acid carbonates or hydroxides.

II Non-carbonate hardness - caused by other calcium and magnesium compounds.

III General hardness is the sum of carbonate and non-carbonate hardness.

Water hardness is expressed in mass units - milligrams (mg $\mathrm{CaCO} 3 / 1)$ or in milligrams equivalent $\mathrm{Ca}$ and $\mathrm{Mg}$ (mval / 1 ( $\mathrm{MgO}$ and $\mathrm{CaCO} 3$ combined)). Degrees of hardness are also used to determine hardness [4]. Most often, water hardness is expressed, also in Poland, in German degrees. On the German degrees scale - the lower the hardness, the softer the water is, while the higher the hardness, the harder the water. The overall hardness of the drinking water should be within 5-20 German degrees [3].

$1^{\circ}$ Polish $=10 \mathrm{mg} \mathrm{Ca} /$ liter of water

$1^{\circ} \mathrm{German}=10 \mathrm{mg} \mathrm{CaO} /$ liter of water

$1^{\circ}$ French $=10 \mathrm{mg} \mathrm{CaCO} 3 /$ liter of water

Carbonate bath salts are used to reduce water hardness [3].

\section{Aim}

The purpose of the work is to detect carbonates in bath salts and water softeners due to the considerable hardness of tap water in Lublin.

\section{Materials and methods}

A total of 80 samples were collected: micellar fluids-5, tonics-6, shampoos-17, shower gels-6, bath salts-13, soaps-11, washing gels-6, softeners-3, washing capsules-3, washing powders-4, dishwasher tablets-5, bathwatercolour-1.

One gram of test substance was weighed, then $10 \mathrm{~cm} 3$ distilled water was added. The vessel with the test substance and water was heated until the precipitate dissolved. To prevent the contents from splashing, they were mixed with a glass rod. The solution was poured into a tube. A few drops of $3 \mathrm{~mol} / \mathrm{dm} 3 \mathrm{H} 2 \mathrm{SO} 4$ were added to the solution. The evolution of gas bubbles indicates the presence of carbonates in the salt [5-9].

In the experiment, 80 substances were used, The experiment used sulfuric acid (Sulfuric Acid) with a concentration of 95-97\%, purchased from Merck (Germany) in a 1 liter bottle.

The presence of $\mathrm{Na} 2 \mathrm{CO} 3$ carbonates confirms the secretion of $\mathrm{CO} 2$ bubbles under the influence of $\mathrm{H} 2 \mathrm{SO} 4$.

$$
\begin{gathered}
\mathrm{H} 2 \mathrm{SO} 4+\mathrm{Na} 2 \mathrm{CO} 3 \rightarrow \mathrm{Na} 2 \mathrm{SO} 4+\mathrm{CO} 2 \uparrow+\mathrm{H} 2 \mathrm{O} \\
\mathrm{H} 2 \mathrm{SO} 4+2 \mathrm{NaHCO} 3 \rightarrow \mathrm{Na} 2 \mathrm{SO} 4+2 \mathrm{CO} 2 \uparrow+2 \mathrm{H} 2 \mathrm{O} \\
\mathrm{H} 2 \mathrm{SO} 4+\mathrm{Na} 2 \mathrm{CO} 3.10 \mathrm{H} 2 \mathrm{O} \rightarrow \mathrm{Na} 2 \mathrm{SO} 4+\mathrm{CO} 2 \uparrow+11 \mathrm{H} 2 \mathrm{O}
\end{gathered}
$$




\section{Results}

In our experiment we have found the presence of bicarbonate only in effervescent tablets for baby baths, Salt Iwonicka and in bathing balls. The foam in the remaining preparations was due to the presence of soaps (in soaps and shampoos) or phosphonates (in powders and liquids for washing and rinsing, and dishwasher detergents).

\section{Discussion}

Hard waters impede the washing process, require the use of much more soaps, detergents and washing agents. The hard water problem is also affecting the industry, causing sludge to form in the various plumbing systems present there. The most known phenomena include the formation of boiler scale [3]. Limescale can be caused by water that is very hard. Of course, the $\mathrm{pH}$ of the water is of great importance here.

It should be known that soft water, characterized by a low content of $\mathrm{Ca}$ and $\mathrm{Mg}$ ions, accelerates the corrosion process taking place in plumbing installations. Also, when filling the iron with water, it should be kept in mind that it will be appropriate to do it straight from the tap or boiled water, because often distilled water used for this purpose can cause corrosion of steel elements. In turn water

with high hardness, it easily creates specific deposits and deposits, which in time reduce the patency of the wires [2].

Bearing in mind human health, medium hardness water is preferred for consumption and hygiene. According to the WHO, significant water hardness does not cause adverse health effects. It is just the opposite.

Hard water can protect the human body against certain diseases, in particular the circulatory system, due to its calcium content. The available results of the research conducted so far are, however, insufficient to prove any cause-effect relationship. Therefore, when determining the value of water hardness, one should not be guided by its impact on human health. Undoubtedly, mineral salts found in hard water, containing calcium or magnesium ions, are important for the human body. Calcium is the main ingredient affecting the degree of water hardness. It is even recommended to keep teeth and bones in excellent shape. Magnesium, however, being a component of drinking water, is about thirty times better absorbed, compared to magnesium supplied with food. Tap water is therefore the easiest way to supplement the demand for magnesium and calcium [2]. Soft water, which is deprived of these elements, may pose a greater danger to the human body than water of greater hardness. Water with low hardness - soft water, promotes corrosive activity and due to this action, it is generally characterized by increased saturation of heavy metals, including lead [10].

Some authors suggests that unusually soft water, with a hardness $<75 \mathrm{mg} / 1$, may have an adverse effect on the body's mineral balance [2]. Many scientists have shown a relationship between arterial pressure and drinking water of considerable hardness [2,11]. It has also been observed that mortality due to cardiovascular disease is increased by about $20 \%$ in people consuming soft water, and it has also been proven that increasing drinking water hardness by $1^{\circ}$ German reduces the risk of heart attack by $1 \%$. Therefore, hard water softening tests should be carefully thought out, especially in the case of softening of drinking water [2].

Drinking water is constantly monitored by sanitary and epidemiological stations. There, its physical and chemical properties, ion and compound concentrations are determined, and bacteriological tests are performed. The laboratories of these stations test physicochemically water on three levels - these are shortened, extended and full sanitary tests. The measurement methods and requirements are described in detail in the relevant regulations [12]. 
The name of the salt comes from the Latin language from the word sal. This term is used for all substances that exhibit properties comparable to those of ancient rock salt, which everyone knows even from the kitchen and uses as a seasoning for most dishes. Rock salt has its chemical name - sodium chloride. However, in science, which is chemistry - salt is a term with a broader meaning [13].

It is worth mentioning that the salts are divided in terms of water solubility. We distinguish salts that are well soluble in water (these include $\mathrm{NaCl}$ and $\mathrm{CuSO} 4$, among others), poorly soluble in water (here we can include, for example, CaSO4 and PbI2), but also salts that dissolve in water with great difficulty (basically not dissolve) - these include $\mathrm{CaCO} 3$ and $\mathrm{Ca} 3(\mathrm{PO} 4) 2$.

The whole group of carbonic acid salts is called carbonates. Carbonic acid belongs to oxygenic acids. When creating carbonate names, you don't specify the valence of a non-metal that comes from the acid residue. The carbonate group includes salts such as, for example, potassium carbonate $(\mathrm{K} 2 \mathrm{CO} 3)$, calcium carbonate $(\mathrm{CaCO} 3)$, and iron carbonate $(\mathrm{Fe} 2(\mathrm{CO} 3) 3$ [13].

In everyday life, salts can be found, for example, in the kitchen or bathroom. In the bathroom you will find them easily in soaps and washing powders - where the ingredient is usually soda ash $(\mathrm{Na} 2 \mathrm{CO} 3)$, in bath salts with sodium chloride $(\mathrm{NaCl})$, potassium chloride $(\mathrm{KCl})$ or magnesium chloride $(\mathrm{MgCl} 2)$, in toothpastes and medicines with magnesium carbonate (MgCO3), in powders, tooth powders and powders with calcium carbonate ( $\mathrm{CaCO} 3)$, due to its absorbent properties and high whiteness. Crystalline sodium carbonate, or crystalline soda $(\mathrm{Na} 2 \mathrm{CO} 3 \cdot 10 \mathrm{H} 2 \mathrm{O})$, is an effective water softening agent used in fabric washing powders, soaps made from fatty acids, foaming agents, creams and lotions

cosmetic. Sodium bicarbonate (NaHCO3), due to its instability at high temperature and under the influence of moisture, is used mainly for the production of bath salts, which foam, and in mineral and carbonic baths. It is safe for the skin because it does not irritate it [13]. Interestingly, washing powders were invented as early as 1878 [14]. In the kitchen, in baking powder, you'll find baking soda (NaHCO3) as a conditioner, and in the salt shaker - sodium chloride $(\mathrm{NaCl})$ - a commonly used spice. For preservation of sausages and meat, potassium nitrate (KNO3) is used [13].

In this work, the bicarbonate content of various cosmetic products was assessed. It was found that carbonates are not found in micellar lotions, face wash gels, soaps, shower gels, bath lotions, but are present in varying amounts in bath salts, and in tablets and bath balls. Iwonicka salt foams in a manner comparable to soda.

Hard water can irritate the skin and contribute to skin diseases. Among those who are required to wash their hands repeatedly (health workers, people working in the production of food and in the trade of food products) may have contact dermatitis or allergic dermatitis [15].

\section{Conclusions}

1. Not all products containing "bath salt" contain bicarbonate.

2. Budget bath salts (produced for chain stores) in the composition have sodium chloride (Sodium Chloride) or sodium lauryl sulfate (Sodium Lauryl Sulfate), while they do not contain bicarbonate.

3. Micellar liquids, shower gels, face wash gels, soaps, shampoos, powders and liquids for washing and rinsing fabrics, dishwasher products do not contain carbonates.

4. The most bicarbonate salt contains Iwonicka Salt. 
5. Detergents such as washing powders, washing liquids and fabric rinses and dishwasher products contain phosphonates, which give off abundant foam.

6. Washing powders of German origin foam more abundantly than those available on the Polish chemical market.

\section{References}

1. Alam M, Gladstone HB, Tung RC. Dermatologia kosmetyczna, Elsevier Urban \& Partner, Wrocław 2011.

2. Zdanowicz A, Płatek B. Twardość wody przeznaczonej do spożycia przez ludzi, Doradztwo Wodne, Milanówek 2018.

3. Brzozowski J, Wawrzyszuk B, Zaborowska W, Kozak H, Ziemińska M. Elementy przyrodnicze w ochronie zdrowia człowieka Wydanie II - poprawione i uzupełnione. Skrypt ćwiczeniowy dla studentów Wydziałów Lekarskiego, Pielęgniarskiego, Stomatologii i Farmacji, Zakład Higieny Ogólnej Instytutu Medycyny Społecznej Akademii Medycznej w Lublinie, Lublin 1986.

4. Borzęcki A. Higiena i środowisko a zdrowie człowieka, Vol III, Lublin 2014.

5. Iwan M, Kurpiel-Gorgol R, Rzączyńska Z. Podstawy chemii w ćwiczeniach. Zestaw ćwiczeń z chemii dla studentów Chemii Środków Bioaktywnych i Kosmetyków, Uniwersytet Marii Curie Skłodowskiej, Lublin 2006.

6. Jasiewicz C, Baran A. Przewodnik do wykładów i ćwiczeń z toksykologii, Wydawnictwo Uniwersytetu Rolniczego w Krakowie, Kraków 2008.

7. Kowal AL, Świderska-Bróż M. Oczyszczanie wody, Wydawnictwo Naukowe PWN, Warszawa 1996.

8. Seńczuk W. Toksykologia, Wydawnictwo Lekarskie PZWL, Warszawa 2002.

9. Wyroba A, Witek E. Oznaczenie twardości wody wód powierzchniowych, ściekowych i uzdatnianych. [W:] Chemia środowiska, cz.1, Ćwiczenia i seminaria, Ed. SzczepaniecCięciak E, Kościelniak P, Wydawnictwo Uniwersytetu Jagiellońskiego, Kraków 1999.

10. Calderon EL, Braun GF. Water hardness and cardiovascular disease. In: Nutrients in drinking water, WHO, Geneva 2005: 117-118.

11. Pasternak K. Magnez w fizjologii człowieka Biuletyn Magnezologiczny, 1999; 4(2): 480485.

12. Jethon Z. Medycyna zapobiegawcza i środowiskowa. Higiena - Ekologia kliniczna Zdrowie. Podręcznik dla studentów, Wydawnictwo Lekarskie PZWL, Warszawa 1997.

13. Gulińska H, Smolińska J. Ciekawa chemia. Podręcznik do klasy 8, Wydawnictwo Szkolne i Pedagogiczne, Warszawa 2017.

14. Kąkolewski I, Kowalewski K, Plumińska-Mieloch A. Historia 7. Podręcznik do szkoły podstawowej, Wydawnictwo Szkolne i Pedagogiczne, Warszawa 2017.

15. WHO Guidelines on Hand Hygiene in Health Care First Global Patient Safety Challenge. Clean Care is Safer Care (https://apps.who.int/iris/bitstream/handle/10665/44102/9789241597906_eng.pdf;jsessionid= B2ADD733665CC536DD12101C2A3AF55A?sequence=1 - cited on June 7th2020). 